\title{
Purification of bovine liver transglutaminase by gel filtration
}

\author{
Seyyed Mohammad Hossein Razavian* ${ }^{*}$, Ali Kashfi and Zohreh Khoshraftar
}

\begin{abstract}
Transglutaminases (TGases) are enzymes that catalyze transfer of acyl group and covalent crosslinks formation between peptide-bound glutaminyl residues and amino groups. TGases have many industrial applications and have been purified from various sources. TGase was purified from the bovine liver extract by gel filtration on Sephacryl S-200 HR column. TGase activity was measured using CBZ-L-glutaminylglycine \& hydroxylamine and the enzyme was characterized with respect to its response to different temperatures, $\mathrm{pHs}$ and salt concentrations. TGase was purified by yield $36.7 \%$, had a weight $74 \mathrm{kDa}$, a high $\mathrm{pH}(\mathrm{pH}=8)$ and temperature $\left(45^{\circ} \mathrm{C}\right)$ optimum. The enzyme was observed to be stable at temperatures below $55^{\circ} \mathrm{C}$ and was stable within a narrow pH range of 6.5-8.0. Purified TGase showed $\mathrm{Ca}^{2+}$ dependent characteristics and tended to retain activity at a high $\mathrm{NaCl}$ concentration. These results revealed that purified TGase can be used as a potential alternative to other sources.
\end{abstract}

Keywords: Transglutaminase, Bovine liver, Purification, Gel filtration, Optimum condition

\section{Introduction}

Transglutaminases (TGase) (EC 2.3.2.13) are a widely distributed group of enzymes that belong to the group of transferases. TGases catalyze the acyl transfer reaction between a free amine group (e.g., in a protein or peptide-bound lysine or an amine) and the $\gamma$-carboxy amide group of proteins or peptide bound glutamine thus leading to the modification of proteins [1]. When an $\varepsilon$-amino group of a peptide bound lysine acts as a acyl acceptor, isopeptide bond is formed between the glutamine and lysine residues in them, introducing both inter- and intramolecular covalent cross-links, resulting in the polymerization of the proteins [1-3].

TGase was first discovered by Heinrich Waelsch more than 40 years ago as a liver enzyme; incorporating amines into proteins [4]. Initial research on the applications of TGases started with the isolation of enzymes from mammalian tissues and body fluids [5-7]. These enzymes showed the possibility to modify the functional

*Correspondence: Razavian@qom-iau.ac.ir

Department of Microbiology, Islamic Azad University, Qom branch, Qom, Iran properties in milk caseins and soybean globulins in the early 1980s [8-10].

TGases have been purified from various animal tissues or organs (such as the liver and hair follicle of guinea pig, pig plasma and human epidermis, erythrocyte, plasma and placenta, fish muscle) $[5,11-14]$, plants $[15,16]$ and microorganisms $[17,18]$. Until late 1980s, guinea pig liver TGase was the only commercially available TGase [19]. However, its scarce source in addition to the laborious purification procedure entailed extremely high prices on the market and the use of TGases as texture enhancer in foods resulting in a low attractiveness for potential industrial applications $[9,10]$.

For industrial applications, large scale production of the enzymes is necessary. Recently, efforts have been made to obtain TGases from microorganisms and used widely as a functional enzyme within various branches of the food industry. Fermentation of TGases derived from microorganisms makes it possible to achieve mass production of them from cheap substrates [9]. However, separation and purification of TGases from plant and animal tissues are still in their infancy.

Other approach is extraction and purification of the TGase from the tissues or body fluids of food-use 
animals, such as fish, swine, and cattle [20]. Now in Europe, blood factor XIII, a certain type of TGase is extracted commercially from the blood of swine and cattle at slaughterhouses [21].

On the other hand the search for new enzymes with novel properties or which displays better characterization than the ones documented is a growing trend and holds a pivotal position in the future of enzyme technology. The overall rational for this study was to discover new source of TGase for potential use to meet the growing demands for enzymes in commercial applications. In this research, TGase from the bovine liver was selected for preliminary purification and characterize with respect to its response to $\mathrm{pH}$ and temperature, in addition to its response to different calcium and sodium chloride concentrations.

\section{Materials}

The following materials: CBZ-glutaminyl glycine, hydroxylamine, L-glutamic acid $\gamma$-mono hydroxamate and reduced glutathione were purchased from Sigma Chemical Co. Bovine serum albumin (BSA), trichloroacetic acid (TCA), ferric chloride hexa hydrate, were purchased from Merck Chemical Co. All other reagents and chemicals were of analytical grade.

\section{Experimental methods}

\section{Sample preparation and enzyme purification}

Fresh bovine liver was received from a local slaughterhouse transported on ice to the laboratory. The tissues were washed by flushing with distilled water and then TGase was purified based on the method described by Worratao and Yongsawatdigul [22] with a slight modification. Approximately $4 \mathrm{~g}$ of liver sample were homogenized in $12 \mathrm{ml}$ of extraction buffer $(0.05 \mathrm{M}$ Tris- $\mathrm{HCl}$, $0.05 \mathrm{M} \mathrm{NaCl}, 0.025 \mathrm{M}$ EDTA and 0.01 M DTT, pH 7.5) at $8,000 \mathrm{rpm}$ in ice bath for $3 \mathrm{~min}$ using a Yellow Line DI 18 basic homogenizer. The homogenate was centrifuged first at $3000 \mathrm{rpm}, 5 \mathrm{~min}$ and then two times at 13,000 rpm for 30 min both at $4{ }^{\circ} \mathrm{C}$ in a Sigma ultracentrifuge. The supernatant solution was loaded on the gel filtration column. The Sephacryl S-200 HR column $(1 \times 87 \mathrm{~cm})$ was packed as per the manufacturer's manual (GE Healthcare). The columns Void Volume determined by blue dextran, which was about $25 \mathrm{ml}$. About $1.2 \mathrm{ml}$ of the homogenate was loaded onto the column equilibrated with $\mathrm{E}$ (elution) Buffer (0.01 M Tris- $\mathrm{HCl} \mathrm{pH} 7.5$ containing $0.1 \mathrm{M}$ $\mathrm{NaCl}, 0.005 \mathrm{M}$ EDTA and $0.002 \mathrm{M} \mathrm{DTT}$ ) and washed at a constant $(2 \mathrm{ml} / \mathrm{min})$ flow rate with the same buffer. Fractions of $1.5 \mathrm{ml}$ were collected and the protein content and TGase activity of each fraction was monitored. The fractions with any activity were pooled and concentrated into $2 \mathrm{ml}$ by a Millipore ultrafiltration membrane (cut-off $30 \mathrm{kDa})$.

\section{Characterization of purified TGase}

The purified TGase was characterized with respect to $\mathrm{pH}$ and temperature (stability and optimum) in addition to effect of Calcium and sodium Chloride salts.

The thermo stability of TGase was studied by incubating the enzyme extract for $60 \mathrm{~min}$ at various temperatures at $5^{\circ} \mathrm{C}$ intervals from 5 to $70{ }^{\circ} \mathrm{C}$ at $\mathrm{pH} 6.0$ and their activity was assayed. Also the effect of temperature on enzyme activity was determined at the same temperatures. The activity was estimated as a percentage, taking maximum change in absorbance as $100 \%$.

The effect of $\mathrm{pH}$ on enzyme stability and activity was determined using various buffers. The enzyme activity was measured after incubation at $37{ }^{\circ} \mathrm{C}$ for $5 \mathrm{~min}$ in buffer solutions of various $\mathrm{pHs}$. Also the effect of $\mathrm{pH}$ on the TGase stability was determined by incubating the enzyme in different $\mathrm{pHs}$ for $30 \mathrm{~min}$ at $37{ }^{\circ} \mathrm{C}$. Activity was estimated as a percentage, taking the maximum $\mathrm{pH}$ change in absorbance as $100 \%$.

The effect of $\mathrm{Na}$ and $\mathrm{Ca}$ ions was investigated by varying the concentration of $\mathrm{CaCl}_{2}$ and $\mathrm{NaCl}$ in the reaction mixture at $0-8$ and $0-0.015 \mathrm{M}$ range respectively.

\section{Protein determination}

Concentration of protein was determined by the Lowry method [23], using bovine serum albumin (BSA) as a standard.

\section{Assay of TGase activity}

The enzyme activity was assayed according to the method of Folk [5]. It was based upon the measurement of peptide-bound $\gamma$-glutamyl hydroxamate formed from $\mathrm{N}$-carbobenzoxy (CBZ)-L-glutaminyl glycine and hydroxylamine as the substrates in the presence of the enzyme and $\mathrm{Ca}^{2+}$.

$$
\begin{aligned}
& \text { CBZ-Gln-Gly + Hydroxylamine } \\
& \quad \rightarrow \text { CBZ-Gln-Gly-Hydroxamate }
\end{aligned}
$$

And then in the presence of TCA a red color iron complex was formed with the produced hydroxamic acid. About $0.5 \mathrm{ml}$ of the sample was mixed with $0.5 \mathrm{ml}$ of the $\mathrm{R}$ (reaction) mixture ( $200 \mu \mathrm{l}$ of $1.0 \mathrm{M}$ Tris-acetate buffer, $150 \mu \mathrm{l}$ of $0.1 \mathrm{M} \mathrm{CBZ-L-Glutaminylglycine,} 50 \mu \mathrm{l}$ of $0.1 \mathrm{M}$ $\mathrm{CaCl}_{2}, 50 \mu \mathrm{l}$ of $2.0 \mathrm{M}$ hydroxylamine and $50 \mu \mathrm{l}$ of $0.2 \mathrm{M}$ reduced glutathione; $\mathrm{pH}$ 6.0) and incubated for $10 \mathrm{~min}$ at $37^{\circ} \mathrm{C}$. Then $0.5 \mathrm{ml}$ of $\mathrm{S}$ (stop) solution (equal volume of $3 \mathrm{M} \mathrm{HCl}, 12 \%(\mathrm{w} / \mathrm{v})$ TCA and $5 \%(\mathrm{w} / \mathrm{v})$ ferric chloride solution in $0.1 \mathrm{M} \mathrm{HCl}$ ) was used to terminate the reaction and the absorbance of the supernatant was measured at $525 \mathrm{~nm}$ immediately. A standard curve was drawn using $\gamma$-mono-hydroxamic acid L-glutamate. 
One enzyme activity unit was defined as the amount of enzyme that catalyzed the formation of $1.0 \mu \mathrm{mol}$ of peptide-bound $\gamma$-glutamyl hydroxamate in each minute at $\mathrm{pH} 6.0$ and at $37^{\circ} \mathrm{C}$. The specific activity was defined as the number of activity units per milligram of protein.

\section{SDS-polyacrylamide gel electrophoresis (SDS-PAGE)}

SDS-PAGE under reducing conditions was carried out according to the method described by Laemmli [24]. Electrophoresis was conducted at a constant voltage of $120 \mathrm{~V}$ in $10 \%$ polyacrylamide gels and the gels were stained with Coomassie Brilliant Blue R-250 overnight.

\section{Results}

\section{Enzyme purification}

About $1.2 \mathrm{ml}$ of the homogenate was applied to the column and eluted. The concentrated fraction of each peak (Fig. 1) was tested for protein and TGase activity and fractions $12-23$ (totally $17 \mathrm{ml}$ ) that had any detectable activity were collected, pooled and concentrated into $2 \mathrm{ml}$ by ultrafiltration membrane. The purification results (Table 1) revealed about twofold increase in specific activity and a $36.7 \%$ recovery yield. SDS-PAGE of the fractions revealed one major band at $74 \mathrm{kDa}$ indicating the preparations were completely homogenous.

\section{Effect of temperature on enzyme}

The thermo-stability of bovine TGase after $60 \mathrm{~min}$ incubation at various temperatures is shown in Fig. 2. The enzyme was stable at temperatures below $55^{\circ} \mathrm{C}$ but was gradually inactivated at higher temperatures. There was no activity observed at refrigerator temperature $\left(4{ }^{\circ} \mathrm{C}\right)$. The activity seems to decrease steadily after $50{ }^{\circ} \mathrm{C}$. The optimal temperature of the bovine TGase was at $45{ }^{\circ} \mathrm{C}$. The activity seems to decrease steadily after $50{ }^{\circ} \mathrm{C}$ and was no activity observed not only at $70{ }^{\circ} \mathrm{C}$ but also at refrigerator temperature $\left(4^{\circ} \mathrm{C}\right)$.

\section{Effect of pH on enzyme}

The enzyme was stable between $\mathrm{pH} 6.5$ and 8.0 when incubated for $30 \mathrm{~min}$ at $35{ }^{\circ} \mathrm{C}$. There was $70 \%$ residual activity above $\mathrm{pH} 7$, however losing of activity in the acidic (below $\mathrm{pH} 4$ and alkaline (above $\mathrm{pH}$ 8.5) regions was remarkable (Fig. 3). Bovine TGase could acylate its substrate over a relatively broad $\mathrm{pH}$ range (4.0-10.0). At low $\mathrm{pH}$ (acidic) enzyme seemed to be inactive. The TGase exhibited higher activity within the $\mathrm{pH}$ range of 6-8 with an optimum at $\mathrm{pH} 8.0$.

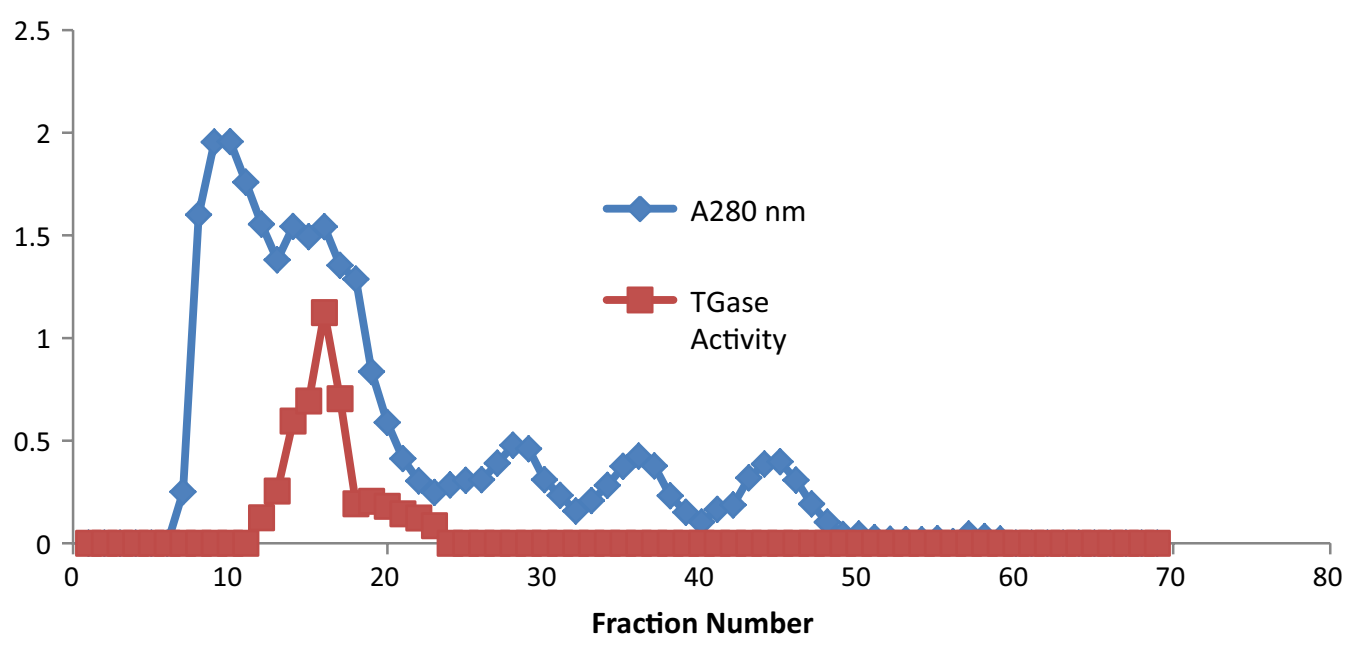

Fig. 1 A $280 \mathrm{~nm}$ of fractions eluted from the size exclusion column after extract loading

Table 1 Summary of procedures employed for purifying of the TGase from the liver of bovine

\begin{tabular}{lllllcll}
\hline Purification step & $\begin{array}{l}\text { Total } \\
\text { volume } \\
(\mathbf{m l})\end{array}$ & $\begin{array}{l}\text { Protein } \\
\text { concentration } \\
(\mathbf{m g} / \mathbf{m l})\end{array}$ & $\begin{array}{l}\text { Total } \\
\text { protein } \\
(\mathbf{m g})\end{array}$ & Activity (U/ml) & Total activity (IU) & $\begin{array}{l}\text { Spcific } \\
\text { activity (U/ } \\
\mathbf{m g})\end{array}$ & $\begin{array}{l}\text { Recovery } \\
(\%)\end{array}$ \\
\hline After homogenization & 1.2 & 69.33 & 83.2 & 9.94 & 11.93 & 0.143 & 100 \\
After gel filtration & 17 & 0.91 & 15.47 & 0.26 & 4.42 & 0.28 & 37 \\
After ultrafiltration & 2 & 7.1 & 14.2 & 2.19 & 4.38 & 0.31 & 36.7 \\
\hline
\end{tabular}




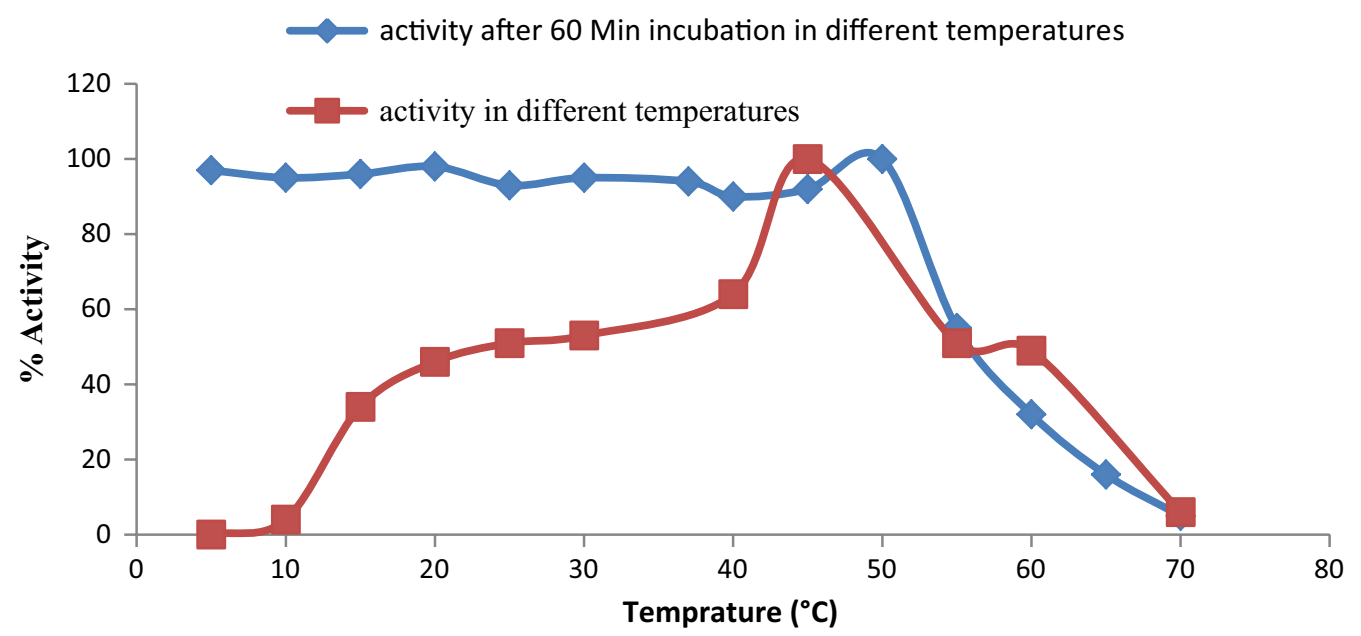

Fig. 2 Relative percent of enzyme activity in different temperatures and after 60 min incubation in different temperatures (assay is performed at pH 6.0 with CBZ-L-glutaminylglycine and hydroxyl amine as substrates)

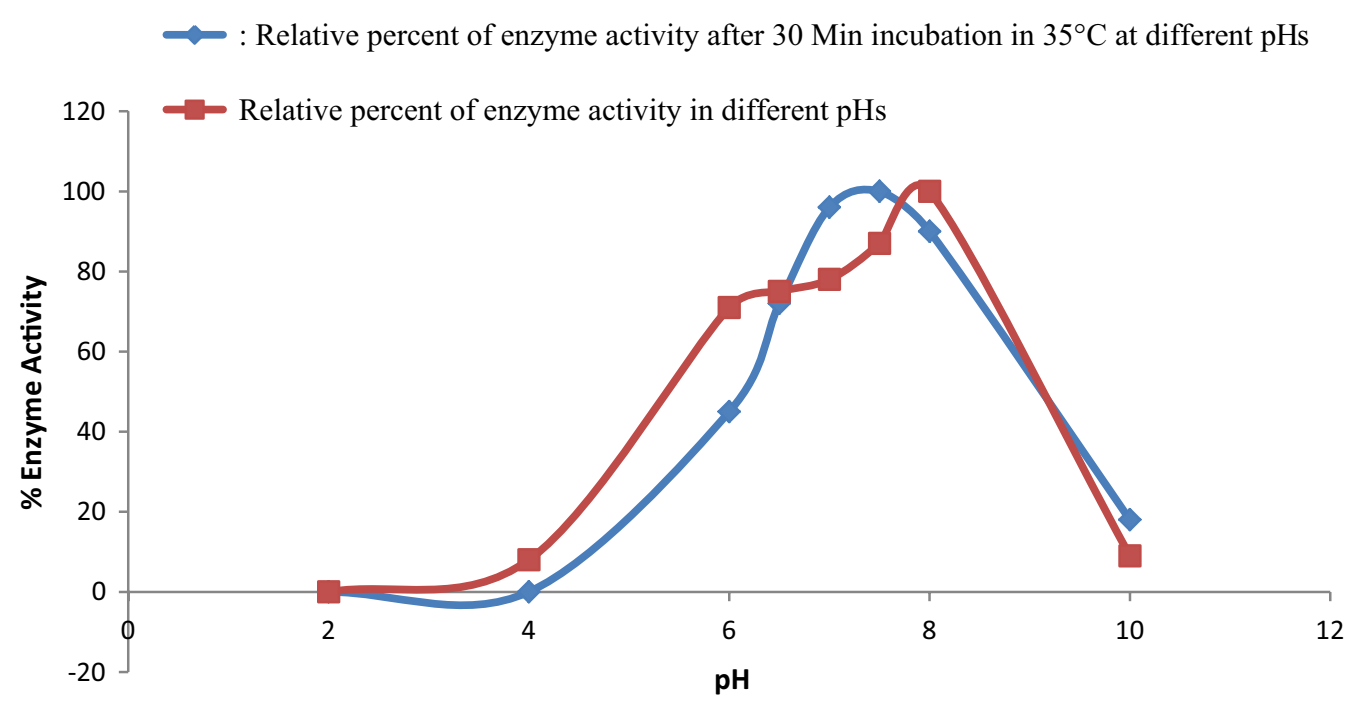

Fig. 3 Relative percent of enzyme activity in different pHs and activity after 30 min incubation in $35^{\circ} \mathrm{C}$ at different pHs $(\mathrm{KCl}-\mathrm{HCl} \mathrm{pH} \mathrm{2.0,} \mathrm{citrate-}$ phosphate $\mathrm{pH} 4.0-6.0$, Tris- $\mathrm{HCl} \mathrm{pH} \mathrm{8.0,} \mathrm{and} \mathrm{carbonate-bicarbonate} \mathrm{pH} 10.0$ ) (assay is performed in $37^{\circ} \mathrm{C}$ with CBZ- L-glutaminylglycine and hydroxyl amine as substrates)

\section{Effect of calcium and sodium chloride}

Purified TGase like other mammalian TGases showed an absolute requirement for calcium ions (Fig. 4) [25] and not only no activity observed in the absence of $\mathrm{Ca}^{2+}$, but also the activity increased with $\mathrm{Ca}^{2+}$ concentration (Fig. 4) and at $0.006 \mathrm{M}$ reached the maximum. These results indicate that purified TGase is $\mathrm{Ca}^{2+}$ dependent. $\mathrm{NaCl}$ slightly reduced the activity of purified TGase. A residual activity of $78 \%$ was found at $0.015 \mathrm{M} \mathrm{NaCl}$.

\section{SDS-PAGE of TGase}

The purity and MW of TGase was examined via SDSpolyacrylamide gel electrophoresis versus molecular weight standards. Appearance of a single band indicating that the prepared enzyme was exhibited a purity of more than $80 \%$. Based on the log MW of the BSA and its relative mobility $\left(R_{f}\right)$, the molecular weight of TGase was determined about $74 \mathrm{kDa}$ (Fig. 5). 


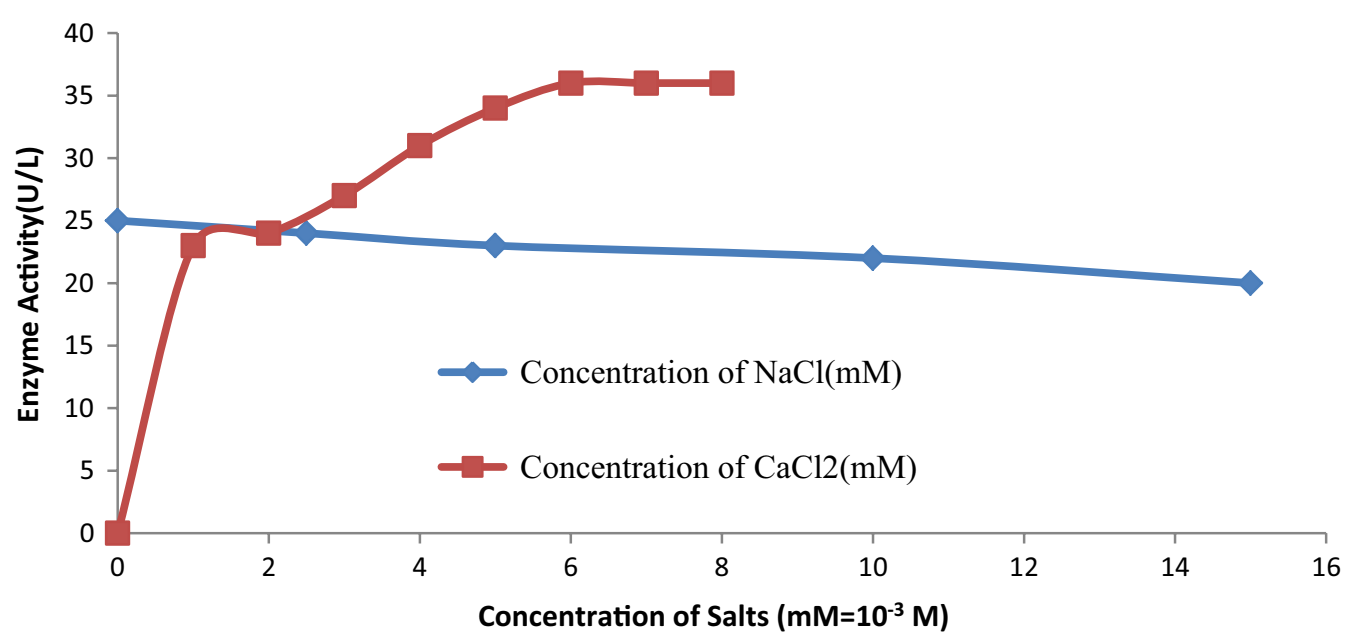

Fig. 4 Effect of different $\mathrm{CaCl}_{2}(0-0.008 \mathrm{M})$ and $\mathrm{NaCl}(0-0.015 \mathrm{M})$ concentrations on the activity of purified bovine liver TGase. (assay is performed in $37^{\circ} \mathrm{C}$ and $\mathrm{pH} 6.0$ with CBZ- L-glutaminylglycine and hydroxyl amine as substrates)

\section{Discussion}

Liver TGase is one of the most widely studied tissue-type TGase although its physiological role is clearly unknown. The rat liver TGase activity is associated with the hepatocytes envelope and may participate in cell to cell contact by forming covalently cross-linked matrices of proteins [26]. Now, TGase is widely used in industries as a protein glue and texture enhancer and its production should be increased. TGase is purified from various animal tissues or organs, plants and microorganisms. Therefore waste tissues such as livers in slaughterhouses could be a novel source from environmental view (Table 2). On the other hands a few researchers have studied and reported different purification methods and yields.

In this research, observed yield (36.7\%) was much lower than reported for other sources [14, 22, 33]. Araki [34] showed that TGase activity vary in different sources and species. Also we should keep it in mind that liver tissue was received from a local slaughterhouse and transported to Lab on ice and according to Leblanc [35] and Vihelmsson (1997) [36], endogenous TGases decreases rapidly after catch.

\section{Effect of temperature on the TGase (activity and stability)}

The thermal stability of purified TGase is shown in Fig. 2. It was observed to be quite stable below $50{ }^{\circ} \mathrm{C}$ and approximately $90 \%$ of the initial activity of enzyme was retained after $60 \mathrm{~min}$ of incubation at $40{ }^{\circ} \mathrm{C}$. However at higher temperatures, the stability decreased with the TGase losing $60 \%$ of activity at $70{ }^{\circ} \mathrm{C}$. The higher thermal stability of bovine TGase may be related to the higher habitat temperature of the animal.
The optimal temperature of bovine TGase was between 40 and $45^{\circ} \mathrm{C}$. There was no activity observed at refrigerator temperature $\left(4^{\circ} \mathrm{C}\right)$ and the activity seems to decrease steadily after $50{ }^{\circ} \mathrm{C}$. This could be due to possible denaturation of the enzyme and a subsequent reduction in its catalytic activity.

Carp TGase showed optimum activity at $30{ }^{\circ} \mathrm{C}$ [37], Pollock liver TGase between 35 and $50{ }^{\circ} \mathrm{C}$ [38] and red sea bream liver between $55-60{ }^{\circ} \mathrm{C}$ [12]. A microbial TGase obtained from Streptoverticillium mobaraense and commercialized by Ajinomoto Co., showed a temperature optimum at $50{ }^{\circ} \mathrm{C}$ [39]. An optimal temperature of $50{ }^{\circ} \mathrm{C}$ is reported for tropical tilapia [22], threadfin bream liver [33] and walleye pollack liver [30]. Slightly higher optimum temperature of $55{ }^{\circ} \mathrm{C}$ was reported in red sea bream liver TGase [12] while TGase from Japanese oyster, Pollock liver and scallop exhibited the best activity between 35 and $50{ }^{\circ} \mathrm{C}[30,38]$. Therefore optimal temperature of TGase tends to vary with sources and as Lee [40] reported, could be related to the species habitat temperature.

\section{Effect of $\mathrm{pH}$ on the TGase (activity and stability)}

The effect of $\mathrm{pH}$ on the stability of the purified TGase was evaluated by measuring enzyme activity after incubation at various $\mathrm{pH}$ conditions for $30 \mathrm{~min}$. TGase was stable within a narrow $\mathrm{pH}$ range of 6.5-8.0 (Fig. 3). This result was similar to those obtained by Nozawa [38] who reported squid gill TGase to be stable at pH 7.5-9.0.

The TGase extract exhibited higher activity within the $\mathrm{pH}$ range of $6-8$ with an optimum at $\mathrm{pH} 8.0$. These results are consistent with those obtained by Worratao [22] and Nozawa [38] who reported an optimum $\mathrm{pH}$ of 


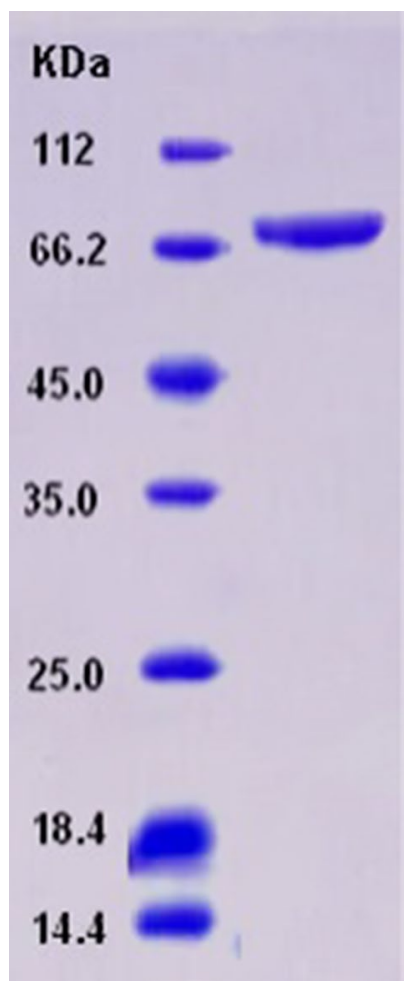

Fig. 5 SDS-PAGE pattern showing the purification of the bovine liver TGase. Lane 1: Molecular Weight Markers, lane 2: purified TGase (74 $\mathrm{KDa}$ ) from the gel filtration chromatography. The concentration of the separating gel was $10 \%$. Migration was from top to bottom

7.0-7.5 for tilapia muscle TGase and 7.5-8.0 for squid gill, respectively. Especially a relatively high $\mathrm{pH}$ optimum (8.5-9.0) was found in red sea bream TGase [12], threadfin bream liver [33], and walleye pollack liver TGase [30].

\section{Effect of calcium and sodium chloride on the activity of TGase}

Observations indicated purified TGase like other mammalian TGases has an absolute requirement for $\mathrm{Ca}^{2+}$ ions and its activity is $\mathrm{Ca}^{2+}$ dependent (Fig. 4) [25]. The enzyme has no activity in the absence of $\mathrm{Ca}^{2+}$, and its activity increased with $\mathrm{Ca}^{2+}$ concentration so at $0.006 \mathrm{M}$ reached the maximum. For showing full activity, TGases from different sources need to various $\mathrm{Ca}^{2+}$ concentrations. TGases from limulus hemocyte and guinea pig liver, for example, needed 0.008 and $0.010 \mathrm{M} \mathrm{Ca}^{2+}$, respectively [32]. TGase purified from red sea bream liver, for full activation, required only $0.0005 \mathrm{M}$ of $\mathrm{Ca}^{2+}$ [12]. Ahvazi [41] reported for activating each human TGase III which is the cytoplasmic TGase expressed in stratified squamous epithelia, three $\mathrm{Ca}^{2+}$ ions is required. The $\mathrm{Ca}^{2+}$ may induce enzyme conformational changes which lead to exposing the active site cysteines (Cys) to a substrate [7]. Noguchi [42] has postulated the
Table 2 Different sources employed for TGase purification

\begin{tabular}{ll}
\hline Source & References \\
\hline Mammals & \\
Human plasma factor XIII & Folk [27] \\
Bovine factor XHla & Folk [27] \\
Guinea pig liver & Folk [27] \\
Rabbit liver & Abe et al. [11] \\
Plant & \\
Pea seedlings & Icekson et al. [15] \\
Alfalfa & Kuehn et al. [16] \\
Microbial & \\
S. mobaranese & Ando et al. [18] \\
Physarum polycephalum & Klien et al. [28] \\
S. ladakanum & Tsai et al. [17] \\
Seafoods & \\
Red sea bream liver & Yasueda et al. [12] \\
Carp muscle & Kishi et al. [29] \\
Walleye Pollack liver & Kumazawa et al. [30] \\
Lobster muscle & Myhrman et al. [31] \\
Japanese oyster & Kumazawa et al. [13] \\
Limulus hemocyte & Tokunaga et al. [32] \\
Scallop, Botan shrimp, Squid, Rainbow Trout, Atka & Nozawa et al. [14] \\
mackerel & \\
\hline
\end{tabular}

$\mathrm{Ca}^{2+}$ binding to a special site on the surface of red sea bream TGase, resulting in structural and conformational changes. Subsequently, tyrosine covering the catalytic Cys is removed. Then the acyl group donor can bind with the Cys and forming an acyl-enzyme intermediate at the active site.

The activity of purified TGase slightly decreased in the presence of $\mathrm{NaCl}$ so at $0.015 \mathrm{M} \mathrm{NaCl}, 78 \%$ of total activity was found (Fig. 4). Nozawa [38] showed the activity of TGases from carp, rainbow trout and atka mackerel are not sensitive to $\mathrm{NaCl}$ up to $0.5 \mathrm{M}$, although this sensitivity was observed in marine invertebrates such as botan shrimp, scallop and squid TGases. Also $\mathrm{NaCl}$ can activate TGase from Japanese oyster and hemocyte [13, 38]. These results indicate that bovine TGase can be used in food products containing up to $0.015 \mathrm{M} \mathrm{NaCl}$ ignoring significant loss in activity.

\section{Acknowledgements}

We thank our colleagues from IAU provided insight and expertise that greatly assisted the research.

This research is carried out in: Islamic Azad University (IAU), Qom Branch, Qom, Iran.

\section{Authors' contributions}

The design and implementation of this research was the responsibility of SMHR and AK, ZK helped him in the preparation of materials and instruments. All authors read and approved the final manuscript. 


\section{Funding}

The research was funded by the IAU(Islamic Azad University-Qom branch) as a research project No. 75899 to Seyyed Mohammad Hussein Razavian Ph.D.

\section{Availability of data and materials}

Not applicable.

\section{Competing interests}

Not applicable.

Received: 14 December 2019 Accepted: 13 January 2020

Published online: 27 January 2020

\section{References}

1. Folk JE (1980) Transglutaminases. Annu Rev Biochem 49:517-531

2. Ichinose A, Bottenus RE, Davie EW (1990) Nucleotide sequence of the gene for the b subunit of human factor XIII. J Biol Chem 265:13411-13414

3. Lorand L, Conrad SM (1984) Transglutaminases. Mol Cell Biochem 58(1-2):9-35

4. Fesus L, Piacentini M (2002) Transglutaminase 2: an enigmatic enzyme with diverse functions. Trends Biochem Sci 27:534-539

5. Folk JE, Cole PW (1966) Mechanism of action of guinea pig liver transglutaminase. I. Purification and properties of the enzyme; identification of a functional cysteine essential for activity. J Biol Chem 241(23):5518-5525

6. Ikura K, Sakurai H, Okumura K, Sasaki R, Chiba H (1985) One-step purification of guinea pig liver transglutaminase using a monoclonal-antibody immunoadsorbent. Agric Biol Chem 49(12):3527-3531. https://doi. org/10.1080/00021369.1985.10867289

7. Jiang ST, Lee JJ (1992) Purification, characterization, and utilization of pig plasma factor XHla. J Agric Food Chem 40:1101-1107

8. Motoki M, Seguro K (1998) Transglutaminase and its use for food processing. Trends Food Sci Technol 9:204-210

9. Zhu Y, Bol J, Rinzema A, Tramper J, Wijngaards G (1999) Transglutaminase as a potential tool in developing novel protein foods. Agro Food Ind HiTech 10(1):8-10

10. Zhu Y, Rinzema A, Tramper J, Bol J (1995) Microbial transglutaminase: a review of its production and application in food processing. Appl Microbiol Biotechnol 44:277-282

11. Abe T, Chung SI, DiAugustine RP, Folk JE (1977) Rabbit liver transglutaminase: physical, chemical, and catalytic properties. Biochemistry 16(25):5495-5501

12. Yasueda H, Kumazawa $Y$, Motoki M (1994) Purification and characterization of a tissue type transglutaminase from red sea bream (Pagrus major). Biosci Biotechnol Biochem 58(11):2041-2045

13. Kumazawa Y, Sano K, Seguro K, Yasueda H, Nio N, Motoki M (1997) Purification and characterization of transglutaminase from Japanese oyster (Crassostrea gigas). J Agric Food Chem 45:604-610

14. Nozawa H, Mamagoshi S, Seki N (1997) Partial purification and characterization of six transglutaminases from ordinary muscles of various fishes and marine invertebrates. Comp Biochem Physiol Part A Mol Integr Physiol 118B:313-317

15. Icekson I, Apelbaum A (1987) Evidence for transglutaminase activity in plant tissue. J Plant Physiol. 84:972-974

16. Kuehn GD, Sotelo M, Morales T, BruceCarver MR, Guzman E, Margosiak SA (1991) Purification and properties of transglutaminase from Medicago satica L. (alfalfa). FASEB J 5:A1510

17. Tsai GJ, Lin SM, Jiang ST (1996) Transglutaminase from Streptovertici-lium ladakanum and application to minced fish product. J Food Sci 61:1234-1238

18. Ando H, Adachi M, Umeda K, Matsuura A, Nonaka M, Uchio R, Tanaka H, Motoki M (1989) Purification and characteristics of a novel transglutaminase derived from microorganisms. Agric Biol Chem 53(10):26132617. https://doi.org/10.1080/00021369.1989.10869735

19. Jaros D, Partschefeld C, Henle T, Rohm H (2006) Transglutaminase in dairy products: chemistry, physics, applications. J Texture Stud 37:113-155
20. Motoki M, Okiyama A, Nonaka M, Tanaka H, Uchio R, Matsura A, Ando H, Umeda K (1989) Novel transglutaminase manufacture for preparation of protein gelling compounds. Japan Patent, JP0127471.

21. Wilson SA (1992) Modifying meat proteins via enzymatic crosslinking. In: 27th meat industry research conference, Hamilton, pp 247-277.

22. Worratao A, Yongsawatdigul J (2005) Purification and characterization of transglutaminase from Tropical tilapia (Oreochromis niloticus). Food Chem 93:651-658

23. Lowry OH, Rosebrough NJ, Fair AL, Randall RJ (1951) Protein measurement with the folin phenol reagent. J Biol Chem 193:265-275

24. Laemmli UK (1970) Cleavage of structural proteins during the assembly of the head of bacteriophage T4. Nature 227:680-685

25. Yongsawatdigul J, Worratao A, Park JW (2002) Effect of endogenous transglutaminase on threadfin bream surimi gelation. J Food Sci 67(9):3258-3263

26. Ikura K, Tsuchiya Y, Sasaki R, Chiba H (1990) Expression of guineapig liver transglutaminase cDNA in Escherichia coli Amino-terminal $\mathrm{N}^{\prime \prime}$-acetyl group is not essential for catalytic function of transglutaminase. Eur J Biochem 187:705-711

27. Folk JE (1983) Mechanism and basis for specificity of transglutaminasecatalyzed epsilon-gamma-glutamyl) lysine bond formation. Adv Enzymol Relat Areas Mol Biol 54:1-56

28. Klein JD, Guzman E, Kuehn GD (1992) Purification and partial characterization of transglutaminase from Physarum polycephalum. J Bacteriol 174(8):2599-2605

29. Kishi H, Nozawa H, Seki N (1991) Reactivity of muscle transglutaminase on carp myofibrils and myosin B. Nippon Suisan Gakkaishi 57(6):1203-1210

30. Kumazawa Y, Nakamishi K, Yasueda H, Motoki M (1996) Purification and characterization of transglutaminase form walleye pollack liver. Fish Sci 62:952-964

31. Myhrman R, Bruner-Lorand J (1970) Lobster muscle transpeptidase. Methods Enzymol 19:765-770

32. Tokunaga F, Yamada M, Miyata T, Ding YL, Hiranaga M, Muta T, Iwanaga S (1993) Limulus hemocyte transglutaminase. J Biol Chem 268:252-261

33. Hemung $\mathrm{BO}$, Yongsawatdigul J (2008) Partial purification and characterization of transglutaminase from threadfin bream (Nemipterus sp.) liver. J Food Biochem 32:182-200

34. Araki H, Seki N (1993) Comparison of reactivity of transglutaminase to various fish actomyosins. Nippon Suisan Gakkaishi 59:711-716

35. Leblanc A, Day N, Menard A, Keillor JW (1999) Guinea pig liver transglutaminase: a modified purification procedure affording enzyme with superior activity in greater yield. Protein Expr Purif 17:89-95

36. Vilhelmsson O (1997) The state of enzyme biotechnology in the fish processing industry. Trends Food Sci Technol 81:266-270

37. Tsukamasa Y, Miyake Y, Ando M, Makinodan Y (2002) Total activity of transglutaminase at various temperatures in several fish meats. Fish Sci 68:929-933

38. Nozawa H, Seki N (2001) Purification of transglutaminase from scallop striated adductor muscle and $\mathrm{NaCl}$-induced inactivation. Fish Sci 67:493-499

39. Batista I, Salterio AT, Mateus MJ (2002) Preliminary characterization of European sardine transglutaminase. J Aquat Food Prod Technol 11(3-4):57-64

40. Lee SS, Chiang CF, Pan BS (1998) Occurence of transgluaminase in grey mullet (Mugil cephalus) muscle and its effect on minced fish products. J Food Biochem 22:475-487

41. Ahvazi B, Kim HC, Kee SH, Nemes Z, Steinert PM (2002) Three-dimensional structure of the human transglutaminase 3 enzyme: binding of calcium ions changes structure for activation. EMBO J 21:2055-2067

42. Noguchi H, Ishikawa K, Yokoyama K, Ohtsukas T, Nio N, Suzuki E (2001) Crystal structure of read sea bream transglutaminase. J Biol Chem 276:12055-12059

\section{Publisher's Note}

Springer Nature remains neutral with regard to jurisdictional claims in published maps and institutional affiliations. 